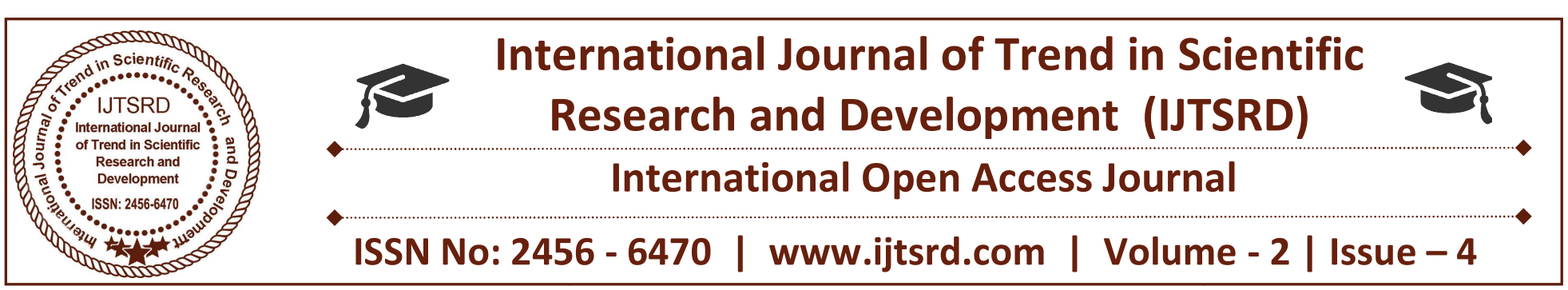

\title{
Development and Stability Enhancement of Two Combine Drugs of Cetirizine and Ambroxol
}

\author{
Natasha Johar*, Tulshi Chakraborty, Vipin Saini \\ M.M College of Pharmacy, Maharishi Markandeshwar Deemed to be University, \\ Mullana, Ambala, Haryana, India
}

\section{ABSTRACT}

Ambroxol Hydrochloride and Cetirizine Hydrochloride are often prescribed together for greater patient acceptability, increased potency, multiple activity, fewer side effects and quick relief. Ambroxol Hydrochloride and Cetirizine Hydrochloride are used for the treatment of bronchitis, cough, and allergy. Conventional Ambroxol and Cetirizine tablet available in the market are not suitable in certain cases such as motion sickness, sudden episodes of allergic attacks, or coughing and when drinking water is not available. Particularly these types of difficulty are faced by pediatric and geriatric patients. An attempt has been made to develop and enhance the stability of two combine drugs Ambroxol Hydrochloride and Cetirizine Hydrochloride, we prepared fast disintegration tablets. Total six formulations (F1-F6) were prepared to study the effect of superdisintegrants shown in Table I. Tablets were prepared by the technique of direct compression methods. Required quantity of each ingredient was taken for each specified formulation. The superdisintegrant, sodium starch glycolate $(1 \%, 2 \%, 4 \%, 6 \%, 8 \%$, and $10 \%)$ concentration was used to develop the tablets. All the ingredients were passed through mesh size \# 60. All the ingredients were cogrind in a pestle motor. Finally talc and Sodium Stearyl fumarate were added and mixed for 5 minutes. The blended excipients were compressed into tablets using tablet compression machine (Madhur Industries, India). The dissolution studied results revealed that in both of the drug Ambroxol Hydrochloride and cetirizine hydrochloride in phosphate buffer $\mathrm{pH} 6.8$ and $\mathrm{pH} 7.4$ dissolution medium were shown within the specified Pharmacopoeias limit.
Keywords: ambroxyol hydrochloride; Cetirizine hydrochloride; cough; allergy; stability enhancement.

\section{INTRODUCTION}

Ambroxol Hydrochloride and Cetirizine Hydrochloride are used for the treatment of Bronchitis, Cough and Allergy [1]. An attempt has been made to develop and enhance the stability of two combined drugs Ambroxol Hydrochloride [AMB] and Cetirizine Hydrochloride [CET]. Ambroxol Hydrochloride officially in Indian Pharmacopoeia (IP) is chemically Trans-4-[(2-amino-3, 5-dibromobenzyl) amino]-cyclohexanol Hydrochloride. It is white or yellowish crystalline powder, sparingly soluble in water, methanol and practically insoluble in methylene chloride $[1,2]$. It depolymerises mucopolysaccharides directly and by liberating lysosomal enzymes which breakdown the fibres in tenacious sputum. It is particularly useful if mucus plugs are present. The breakdown of acid mucopolysaccharide fibers makes the sputum thinner and less viscous, therefore easily removed by coughing [3]. It acts as a bronchosecretolytic and expectorant drug. It stimulates the transportation of the viscous secretions in the respiratory organs and reduces the accumulation of the secretions [4]. Ambroxol Hydrochloride (AMB) is semisynthetic derivative of vasicine obtained from Indian shrub Adhatoda vasica. It is a metabolic product of bromhexine, used in a variety of respiratory disorders including chronic bronchitis and is also used in the treatment of cough [5]. Its molecular weight is 414.6 $\mathrm{g} /$ mole, dissociation constant $(\mathrm{pKa}) 8.2$ and half life is $8.8 \mathrm{hr}$ and melting point is $235^{\circ} \mathrm{C}$ to $240^{\circ} \mathrm{C}[3,6]$. 
Cetirizine is a selective, second-generation histamine H1 receptor antagonist $[7,8]$. Chemically cetirizine hydrochloride, 2-(2-(4- $((4-$ chlorophenyl)(phenyl)methyl)piperazin-1-

yl)ethoxy)acetic acid hydrochloride [8]. It is white or almost white powder, freely soluble in water, practically insoluble in acetone and in methylene chloride [9, 10]. Cetirizine hostile to H1 specificity seems exceptional in being without activity on receptors other than $\mathrm{H} 1$ receptor, most intense antihistamine in the skin and the lung [11]. It has long duration of activity and low potential for interaction with drugs metabolised by the hepatic cytochrome P450 system, inhibiting histamine-induced wheal and flare responses and also possessing inhibitory effects on eosinophil chemotaxis [12-13]. A dose of cetirizine $10 \mathrm{mg}$ every day adequately controls or keeps the indications of unfavorably susceptible diseases [14]. CTZ is less extensively metabolised than different antihistamines and roughly $60 \%$ of a managed measurement is discharged unaltered in $24 \mathrm{hr}$ [15]. This drug widely used for symptomatic relief in urticaria, allergic rhinitis, chronic urticaria, and pollen-induced asthma [10]. Cetirizine has the upsides of noncardiotoxicity as compare to other $\mathrm{H} 1$ antihistamines [16]. The concept of nast dissolving/disintegrating tablets emerged from the desire to provide patients with more conventional means of taking their medication when drinking water is not available and in certain cases such as motion sickness, sudden episodes of allergic attacks, or coughing. Particularly these types of difficulty are faced by pediatric and geriatric patients. Recent developments in technology have presented viable dosage alternatives for pediatric, geriatric, bedridden, nauseous or noncompliant patients.

\section{Materials}

Ambroxol Hydrochloride and Cetirizine Hydrochloride were Gift samples from Crystal Pharmaceuticals, Ambala, $\beta$-Cyclodextrin, Mannitol, Lactose, Sodium Starch Glycolate, Polyvinylpyrrolidone K-30, Sodium Saccharin, Sodium Stearyl Fumarate, and Talc. All chemicals and reagents were used analytical grade.

\section{Methods}

\section{Selection of Excipients and Optimization of Their Concentration}

In the development of stable fast disintegrating tablets, the most important parameters that needs to be optimized are disintegration time and stability study. The tablets were prepared using different excipients (binders and superdisintegrants) and then evaluated for various parameters like friability, hardness and disintegration time. Among them best formulation was selected for further study like dissolution test and stability study.

\section{Optimization of Superdisintegrant Sodium Starch Glycolate}

Total six batches formulation (F1-F6) were prepared, shown in Table I. Tablets were prepared by the technique of direct compression. Required quantity of each ingredient was taken for each specified formulation. The superdisintegrant, Sodium Starch Glycolate $(1 \%, 2 \%, 4 \%, 6 \%, 8 \%$, and $10 \%$ concentration) was used to develop the tablets. All the ingredients were passed through mesh size \#60. All the ingredients were cogrind in a pestle motor and finally talc and Sodium Stearyl Fumarate were added and mixed for 5 minutes. The mixed blend of excipients was compressed into tablets using tablet compression machine (Madhur Industries, India).

Table I: Composition of Tablets

\begin{tabular}{|l|l|l|l|l|l|l|l|}
\hline Sr. No & \multicolumn{1}{|c|}{ Ingredients } & \multicolumn{1}{|c|}{ F1 } & \multicolumn{1}{|c|}{ F2 } & \multicolumn{1}{|c|}{ F4 } & \multicolumn{1}{|c|}{ F5 } & \multicolumn{1}{|c|}{ F6 } \\
\hline 1 & Ambroxol Hydrochloride $(\mathrm{mg})$ & 30 & 30 & 30 & 30 & 30 & 30 \\
\hline 2 & Cetirizine Hydrochloride $(\mathrm{mg})$ & 5 & 5 & 5 & 5 & 5 & 5 \\
\hline 3 & $\beta$-Cyclodextrin $(\mathrm{mg})$ & 50 & 50 & 50 & 50 & 50 & 50 \\
\hline 4 & Mannitol $(\mathrm{mg})$ & 48 & 46 & 42 & 38 & 34 & 30 \\
\hline 5 & Lactose $(\mathrm{mg})$ & 50 & 50 & 50 & 50 & 50 & 50 \\
\hline 6 & Sodium Starch Glycolate $(\mathrm{mg})$ & 2 & 4 & 8 & 12 & 16 & 20 \\
\hline 7 & Polyvinylpyrrolidone K-30 (mg) & 4 & 4 & 4 & 4 & 4 & 4 \\
\hline 8 & Sodium Saccharin (mg) & 5 & 5 & 5 & 5 & 5 & 5 \\
\hline 9 & Sodium Stearyl Fumarate $(\mathrm{mg})$ & 3 & 3 & 3 & 3 & 3 & 3 \\
\hline 10 & Talc (mg) & 3 & 3 & 3 & 3 & 3 & 3 \\
\hline
\end{tabular}




\section{EVALUATION PARAMETERS OF PREPARED TABLETS [17] \\ Post compression Parameters}

\section{Hardness test}

The hardness of three randomly selected tablets from each formulation was determined using Monsanto hardness tester by placing each tablet diagonally between the two plungers and applying pressure until the tablet broke down into two parts completely and the reading on the scale was noted down in $\mathrm{Kg} / \mathrm{cm}^{2}$. The hardness of the formulations was shown in Table II.

\section{Thickness}

The thickness of three randomly selected tablets from each formulation was determined in $\mathrm{mm}$ using a Vernier caliper. The thickness of the formulations was shown in Table II.

\section{Friability test}

Friability was determined by weighing 20 tablets after dusting. Placing 20 tablets in the friabilator and rotating the plastic cylinder vertically at $25 \mathrm{rpm}$ for 4 min. After dusting, the total remaining weight of the tablets was recorded and the percent friability was calculated as:

$\%$ Friability $=[($ Weight Final - Weight Original $) /$ Weight Original $\times 100$. The friability test results of the formulations were shown in Table II.

\section{Uniformity of weight}

The weight $(\mathrm{mg})$ of each of 20 individual tablets, selected randomly from each formulation was determined by dusting each tablet off and placing it in an electronic balance. The weight data from the tablets were analyzed for sample mean and percent deviation. The weight variation test results of the formulations were shown in Table II.

\section{DRUG CONTENT UNIFORMITY $[\mathbf{9}, 17]$}

Each batches ten tablets were powdered and the blend equivalent to $30 \mathrm{mg}$ of Ambroxol Hydrochloride and $5 \mathrm{mg}$ of cetirizine hydrochloride was weighed and dissolved in suitable quantity of $6.8 \mathrm{pH}$ phosphate buffer. The solution was sonicated, filtered, and suitably diluted and the drug content was determined from simultaneous equation method by using Double Beam UV Spectrophotometer (UV-1800 Shimadzu) at $244 \mathrm{~nm}$ and $230 \mathrm{~nm}$ wavelengths corresponding to Ambroxol Hydrochloride and cetirizine hydrochloride, respectively. Each sample was analyzed in triplicate, and mean $\pm \mathrm{SD}$ was calculated and the resulted data were shown in Table II.

Surface pH Study: The tablets $(n=3)$ were made in contact with $1 \mathrm{ml}$ of distilled water and allowed to swell for $2 \mathrm{hr}$ at room temperature. The $\mathrm{pH}$ was measured by bringing the $\mathrm{pH}$ meter electrode (Max 962-p) in contact with the surface of the tablet and allowing it to equilibrate for $1 \mathrm{~min}$. The surface $\mathrm{pH}$ studied results of the formulations were shown in Table II.

\section{Disintegration study}

The disintegration test is conducted using the disintegration test apparatus (Electro lab disintegration test apparatus). The vessel is provided with a thermostat to regulate the temperature of the fluid medium to the desired temperature. The test was carried out on 6 tablets of each batches formulation using disintegration media, hydrochloric acid $\mathrm{pH} 1.5$ at temperature $37.5^{\circ} \mathrm{C} \pm 2^{\circ} \mathrm{C}$. The time in seconds is taken for complete disintegration of the tablet, so that no palatable mass remaining in the apparatus. The study was performed in triplicate and mean $\pm \mathrm{SD}$ was calculated and the results of the formulations were shown in Table II.

\section{In vitro dissolution study [17]}

In vitro drug release of the prepared mouth dissolving tablets was carried out using USP- type II dissolution apparatus (paddle type). The dissolution medium, $900 \mathrm{ml}$ saline phosphate buffer medium of $\mathrm{pH} 6.8$, was placed into the dissolution flask maintaining the temperature of $37 \pm 0.5^{\circ} \mathrm{C}$ and $50 \mathrm{rpm}$. One tablet was placed in each bucket of dissolution apparatus. The apparatus was allowed to run for 50 minutes. Samples measuring $5 \mathrm{ml}$ were withdrawn after every $10,20,30,40$, and 50 minutes using a pipette. During sampling samples were filtered by $0.45 \mu \mathrm{m}$ syringe filter. The fresh dissolution medium was replaced every time with the same quantity of the withdrawn sample. Collected samples were suitably diluted and the drug content was determined from simultaneous equation method by using Double Beam UV Spectrophotometer (UV-1800 Shimadzu) at $244 \mathrm{~nm}$ and $230 \mathrm{~nm}$ wavelengths corresponding to Ambroxol Hydrochloride and cetirizine hydrochloride respectively. Each sample was analyzed in triplicate.

Same procedure was carried out in saline phosphate buffer medium $\mathrm{pH} 7.4$ and the resulted data were summarized in Table III, Table IV and Figure 1, Figure 2. 
International Journal of Trend in Scientific Research and Development (IJTSRD) ISSN: 2456-6470

Stability studies:

Stability study was performed at a temperature of $40 \pm 2{ }^{\circ} \mathrm{C}$ at $75 \% \mathrm{RH}$, over a period of three months $(90$ days). Sufficient number of tablets (20) were packed in amber colored screw capped bottles and kept in stability chamber maintained at $40^{\circ} \pm 2^{\circ} \mathrm{C} \& 75 \% \mathrm{RH}$.
Samples were taken at monthly intervals and performed to determine the percentage of drug degraded at a temperature of $40^{\circ} \pm 2 \mathrm{C}$ and at $75 \%$ Relative Humidity. The resulted data were shown in Table V.

\section{RESULTS}

Table II: Evaluation parameters of Tablets

\begin{tabular}{|c|c|c|c|c|c|c|c|}
\hline $\begin{array}{l}\text { Formulation } \\
\text { code }\end{array}$ & $\begin{array}{l}\text { Mean } \\
\text { Hardness } \\
\mathrm{Kg} / \mathrm{cm} 2\end{array}$ & $\begin{array}{l}\text { Diameter } \\
\text { and } \\
\text { Thickness } \\
\text { (mm) }\end{array}$ & $\begin{array}{l}\text { Friability } \\
\% \mathrm{w} / \mathrm{w}\end{array}$ & $\begin{array}{l}\text { Uniformity } \\
\text { weight } \\
\text { (mg) }\end{array}$ & $\begin{array}{l}\text { Mean } \\
\text { drug } \\
\text { content } \\
\% \pm S D \text {, } \\
n=3\end{array}$ & $\begin{array}{l}\text { Tablet } \\
\text { Surface } \\
\text { pH }\end{array}$ & $\begin{array}{l}\text { Disintegration } \\
\text { time (sec) } \pm \text { S.D }\end{array}$ \\
\hline F1 & 4.47 & $8.1,3.9$ & & 200.3 & $\begin{array}{l}\text { AMB } \\
103.5 \pm 2.3 \\
\text { CET } \\
102.8 \pm 1.8\end{array}$ & 6.9 & $102 \pm 4.34$ \\
\hline F2 & 4.43 & $\begin{array}{r}8.1,3.9 \\
0 \quad \\
0\end{array}$ & $\begin{array}{l}0.52 \\
\text { ern } \\
\text { Tre }\end{array}$ & $\begin{array}{l}200 \\
n a l= \\
n S C\end{array}$ & $\begin{array}{l}\text { AMB } \\
102.5 \pm 2.4 \\
\text { CET } \\
102.8 \pm 1.6\end{array}$ & 7 & $90 \pm 2.31$ \\
\hline F3 & 4.5 & $\begin{array}{c}8.1,3.9 \\
0 \\
0\end{array}$ & $0.56 \mathrm{ese}$ & $\begin{array}{l}200.2 \mathrm{and} \\
\text { opment }\end{array}$ & $\begin{array}{l}\text { AMB } \\
103.5 \pm 2.6 \\
\text { CET } \\
104.8 \pm 1.7\end{array}$ & 7.1 & $81 \pm 1.64$ \\
\hline $\mathrm{F} 4$ & 4.38 & $8.1,3.9$ & $0.51 \mathrm{~N}: ?$ & $200=6470$ & $\begin{array}{l}\text { AMB } \\
101.5 \pm 1.3 \\
\text { CET } \\
103.8 \pm 1.8\end{array}$ & & $72 \pm 1.44$ \\
\hline F5 & 4.49 & $8.1,3.9$ & 0.58 & 200.1 & $\begin{array}{l}\text { AMB } \\
104.5 \pm 2.4 \\
\text { CET } \\
100.8 \pm 1.2\end{array}$ & 7.2 & $62.8 \pm 2.39$ \\
\hline F6 & 4.32 & $8.1,3.9$ & 0.4 & 200 & $\begin{array}{l}\text { AMB } \\
103.5 \pm 2.3 \\
\text { CET } \\
102.8 \pm 1.8 \\
\end{array}$ & 7 & $52 \pm 2.34$ \\
\hline
\end{tabular}


International Journal of Trend in Scientific Research and Development (IJTSRD) ISSN: 2456-6470

Table III Cumulative \% drug released (CET and AMB) in saline phosphate buffer pH 6.8 dissolution medium

\begin{tabular}{|l|l|l|}
\hline Time (minutes) & $\begin{array}{l}\text { Cumulative \% drug release } \\
\text { (CET) in saline phosphate } \\
\text { buffer pH 6.8 dissolution } \\
\text { medium }\end{array}$ & $\begin{array}{l}\text { Cumulative \% drug release } \\
\text { (AMB) in saline phosphate } \\
\text { buffer pH 6.8 dissolution } \\
\text { medium }\end{array}$ \\
\hline 0 & 0 & 0 \\
\hline 10 & 88 & 25 \\
\hline 20 & 100.4 & 72 \\
\hline 30 & 100.3 & 91 \\
\hline 40 & 100.3 & 100 \\
\hline 50 & 100.3 & 100.2 \\
\hline
\end{tabular}

Figure 1 Cumulative \% drug released (CET and AMB) in phosphate buffer pH 6.8 dissolution medium.

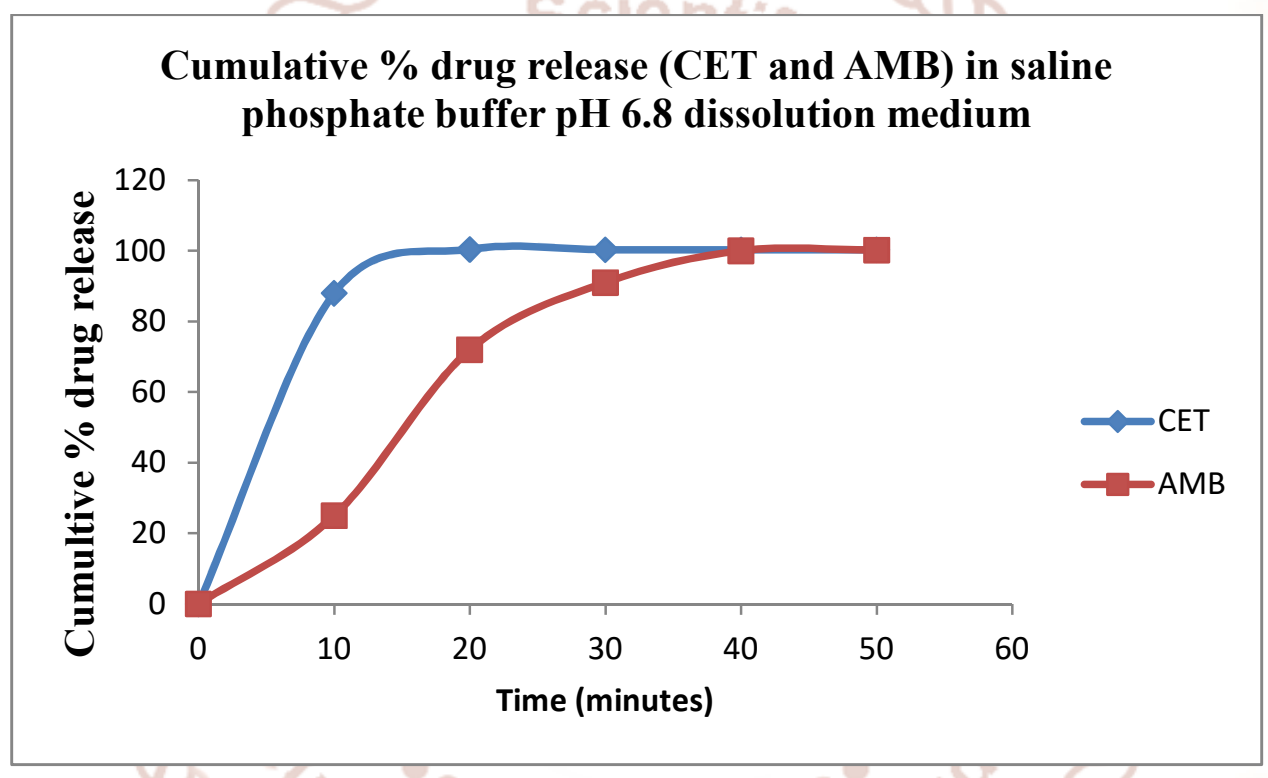

Table IV Cumulative \% drug released (CET and AMB) in saline phosphate buffer pH 7.4 dissolution medium

\begin{tabular}{|l|l|l|}
\hline Time (minutes) & $\begin{array}{l}\text { Cumulative \% drug release } \\
\text { (CET) in saline phosphate } \\
\text { buffer pH 7.4 dissolution } \\
\text { medium }\end{array}$ & $\begin{array}{l}\text { Cumulative \% drug release } \\
\text { (AMB) in saline phosphate } \\
\text { buffer pH 7.4 dissolution } \\
\text { medium }\end{array}$ \\
\hline 0 & 0 & 0 \\
\hline 10 & 94 & 31 \\
\hline 20 & 100.1 & 81 \\
\hline 30 & 100.1 & 99 \\
\hline 40 & 100.1 & 100.1 \\
\hline 50 & 100.1 & 100.1 \\
\hline
\end{tabular}


Figure 2 Cumulative \% drug released (CET and AMB) in saline phosphate buffer pH 7.4 dissolution medium

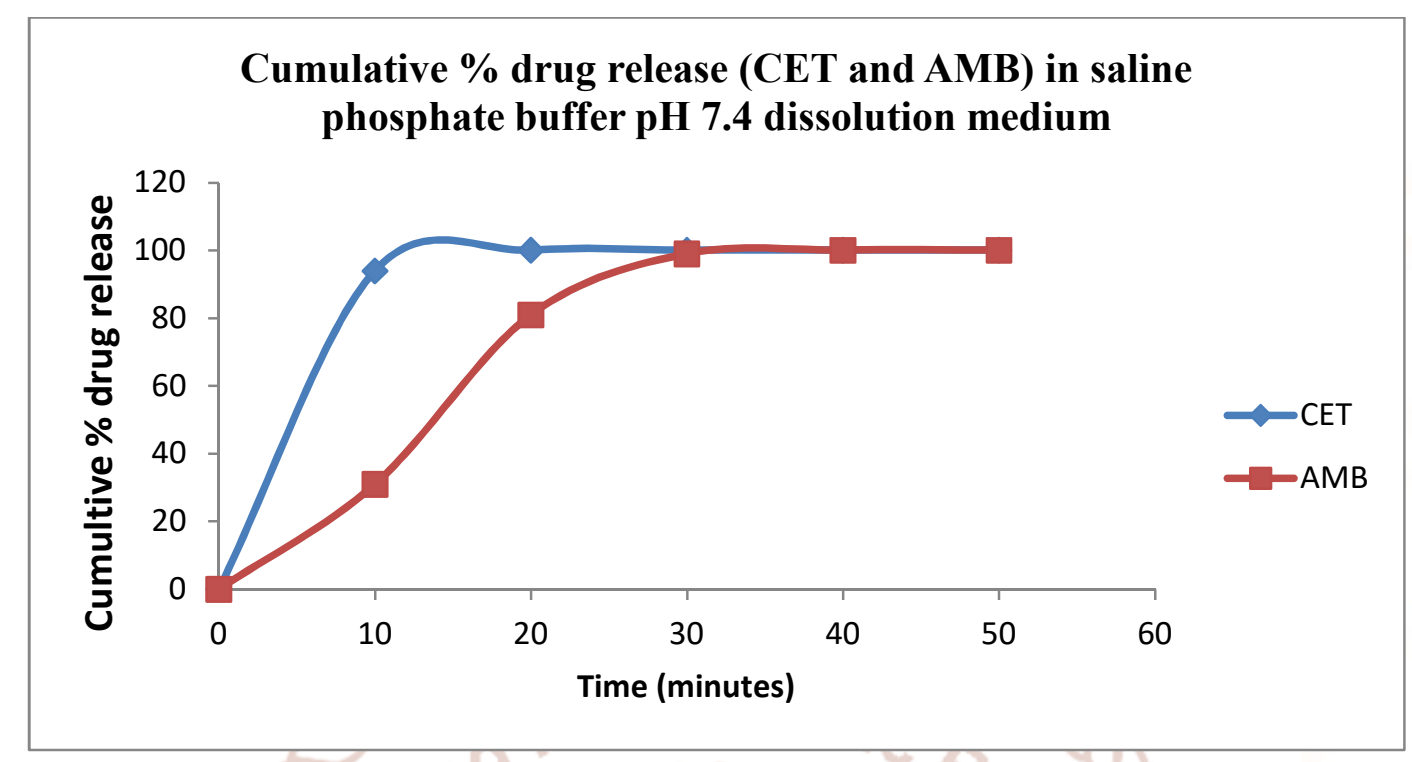

Table V Stability studied results of F6 formulation

\begin{tabular}{|l|c|c|c|c|}
\hline \multicolumn{1}{|c|}{ F6 } & $1^{\text {st }}$ day & $3^{\text {th }}$ day & $\mathbf{6 0}^{\text {th }}$ day & $9^{\text {th }}$ day \\
\hline $\begin{array}{l}\text { Formulation } \\
\text { Content CET }\end{array}$ & $99.998 \pm 0.0518 \%$ & $99.973 \pm 0.0563 \%$ & $99.690 \pm 0.0896 \%$ & $99.583 \pm 0.0723 \%$ \\
\hline $\begin{array}{l}\% \text { Drug } \\
\text { content AMB }\end{array}$ & $99.912 \pm 0.0518 \%$ & $99.54 \pm 0.026 \%$ Ci & $99.53 \pm 0.016 \%$ & $99.42 \pm 0.086 \%$ \\
\hline
\end{tabular}

\section{Result and conclusion:}

The disintegration time of F6 formulation was minimum than the other formulations and it was found to be $62.8 \pm 2.39$ seconds. And the dissolution studies results of $\mathrm{F} 6$ formulation in saline phosphate buffer $\mathrm{pH} 6.8$ dissolution medium, cumulative \% drug released of CET was found to be $100.4 \%$ at $20 \mathrm{~min}$. and $\mathrm{AMB} 72 \%$ at 20 minutes. Also in saline phosphate buffer $\mathrm{pH} 7.4$ dissolution medium, cumulative \% drug released of CET was found to be $100.1 \%$ at $20 \mathrm{~min}$. and $\mathrm{AMB} 81 \%$ at $20 \mathrm{~min}$. The result of the stability study of F6 formulation indicated that there were not much more differences in hardness, disintegration time, drug content uniformity, and friability before and after the stability study $\left(40 \pm 2^{\circ} \mathrm{C}\right.$ at $\left.75 \% \mathrm{RH}\right)$. So from the above studied results revealed that F6 formulation of two combine drugs cetirizine hydrochloride and Ambroxol hydrochloride tablets were stable and the drugs released were fast than the others formulations.

\section{ACKNOWLEDGEMENTS}

This study was supported by the M.M College of Pharmacy, Maharishi Markandeshwar (Deemed to be University) Mullana, Ambala, Haryana-133207, India.

\section{Reference:}

1. Indian Pharmacopoeia. Indian Pharmacopoeia Commission, Ministry of Health \& Family Welfare, Government of India. 2010; vol 12:148,264,792.

2. Buchupalli P, Medidi S. RP-HPLC method for the simultaneous estimation of ambroxol hydrochloride and fexofenadine hydrochloride in bulk and in a tablet mixture. J Appl Pharm Sci. 2015;5(2):074-080.

3. Zahoor A, Munir H, Hussain S, Sheikh ZA, Usmanghani K. A Rapid and Simultaneous Determination of Ambroxol Hydrochloride , Methyl Parabene and Propyl Paraben in Mucol Ambroxol Syrup Dosage Form. RADS-JPPS. 2016; 4(1): 84-88. 
4. Bhatia NM, Ganbavale SK, Bhatia MS, More HN, Kokil SU. RP-HPLC and Spectrophotometric Estimation of Ambroxol Hydrochloride and Cetirizine Hydrochloride in Combined Dosage Form. Indian J Pharm Sci. 2008; 70(5): 603-608.

5. Tripathi K D. Essential of Medical Pharmacology. Jaypee Brothers Medical Publishers, New Delhi, India, 2013; $7^{\text {th }}$ Edition: 219,221 .

6. Rupali R, Dhot K, Llango K, Shabbeer S. Pharmacokinetic studies of ambroxol hydrochloride microspheres in rats after oral administration. International journal of research in pharmacy and chemistry. 2012; 2(2): 280-288.
15. Martin K, Diana S. Pharmacology of Antihistamines. Indian J Dermatol. 2013; 58(3): 219-224.

16. Ingle N V. Preparation and evaluation of Ambroxol Hydrochloride matrix tablet using different combination of polymers. Int $\mathrm{J}$ PharmTech Res. 2011; 3(1): 309-313.

17. Chakraborty T, Saini V, Narwal P, Gupta S. Formulation and evaluation of both stomach and intestine drug delivery system from unit solid dosage tablet formulation. World journal of pharmacy and pharmaceutical sciences. 2015; 4(10):1377-1392.

7. Zhang L, Cheng L, Hong J. The clinical use of cetirizine in the treatment of allergic rhinitis. Pharmacology. 2013; 92(1-2): 14-25.

8. Lee Barnes C, Mckenzie CA, Webster KD, Poinsett-Holmes K. Cetirizine: A New, Nonsedating Antihistamine, Ann Pharmacother. 1993; 27(4): 464-470.

9. Sharma D, Singh M, Kumar D, Singh G. Simultaneous Estimation of Ambroxol Hydrochloride and Cetirizine Hydrochloride in Pharmaceutical Tablet Dosage Form hy Simultaneous Equation Spectrophotometric Method: A Quality Control Tool for Dissolution Studies. ISRN Anal Chem. 2014;1-6.

10. Snowman M, Synder H. Cetirizine:Action on neurotransmitter receptors. Journal of Allegy and Clinical Immunology.1990; 86(6): 1025-1028.

11. Uchida M, Nakahaa H. Phamacological and chemical properties of cetiizine.Nihon Yakuigaku Zasshi. 2000;115(4): 229-35

12. Curan MP, Scott LJ, Perry CM.Cetirizine:a review of its use in allergic disorders. Drugs 2004; 64(5): 523-61

13. Grant JA, Nicodemus CF, Findlay SR. Cetirizine in patients with seasonal rhinitis and concomitant asthma: prospective, randomized, placebocontrolled trial. J Allergy Clin Immunol. 1995; 95(5): 923-932.

14. Derakhshandeh K. Oral Bioavailability and Pharmacokinetic Study of Clarithromycin in Different Dosage Forms in Iranian Healthy Volunteers. J Bioequiv Availab. 2014; 6(6): 206211. 